Florida International University FIU Digital Commons

\title{
Post-College Transition: A Study of Evangelical Spirituality in Emerging Adulthood
}

Katharine R. Pals

Florida International University, kpals001@fiu.edu

DOI: $10.25148 /$ etd.FI14040864

Follow this and additional works at: https://digitalcommons.fiu.edu/etd

Part of the Christianity Commons, and the Developmental Psychology Commons

\section{Recommended Citation}

Pals, Katharine R., "Post-College Transition: A Study of Evangelical Spirituality in Emerging Adulthood" (2014). FIU Electronic Theses and Dissertations. 1173.

https://digitalcommons.fiu.edu/etd/1173 


\title{
FLORIDA INTERNATIONAL UNIVERSITY
}

\author{
Miami, Florida
}

\section{POST-COLLEGE TRANSITION: A STUDY OF EVANGELICAL SPIRITUALITY IN EMERGING ADULTHOOD}

A thesis submitted in partial fulfillment of

the requirements for the degree of

MASTER OF ARTS

in

RELIGIOUS STUDIES

by

Katharine R. Pals 
To: Dean Kenneth G. Furton

College of Arts and Sciences

This thesis, written by Katharine R. Pals, and entitled Post-College Transition: A Study of Evangelical Spirituality in Emerging Adulthood, having been approved in respect to style and intellectual content, is referred to you for judgment.

We have read this thesis and recommend that it be approved.

Whitney A. Bauman

Lesley A. Northup

Christine E. Gudorf, Major Professor

Date of Defense: March 26, 2014

The thesis of Katharine R. Pals is approved.

Dean Kenneth G. Furton
College of Arts and Sciences

Dean Lakshmi N. Reddi University Graduate School

Florida International University, 2014 


\section{DEDICATION}

This study is dedicated to my mother, Phyllis Balzer Pals, in recognition of her intuitive skills in understanding people and to my friends and peers among America's emerging adults in the hope that they may acquire a similar capacity to understand their faith, family and future. 


\section{ACKNOWLEDGMENTS}

I offer my thanks to all those who have helped with the completion of this study. I would like to express my thanks to the faculty of the Religious Studies Department at FIU for the opportunity to participate in this program and for allowing me the creative freedom to explore a somewhat foreign area of research within our department.

Completing this project would not have been possible without the help and expertise of my major professor, Christine Gudorf, and my committee members, Whitney Bauman and Lesley Northup. I express my thanks to my friends and peers in the Religious Studies Department and greater FIU community. Your support and encouragement has left guiding marks on this study.

Much appreciation goes to the FIU student organization leaders and participants for their help in providing access to my sample population. I am grateful to those of you who have openly shared with me your post-college journeys and allowed your words to form the backbone of this research. I offer my thanks, also, for your time and interest in my study.

Finally, I express my gratitude toward my parents, family and friends. To those of you who have listened to seeds of this study develop over coffee, lent data collection expertise, supported my ambitions relentlessly, even from miles away, and always believed in me: thank you. 
ABSTRACT OF THE THESIS

POST-COLLEGE TRANSITION: A STUDY OF EVANGELICAL SPIRITUALITY IN

EMERGING ADULTHOOD

by

Katharine R. Pals

Florida International University, 2014

Miami, Florida

Professor Christine E. Gudorf, Major Professor

This thesis explores the question: How are the spiritual lives of evangelical Christian FIU graduates affected during the two to four years following their college graduation? In twenty mini-case studies participants describe their patterns in prayer life, devotion, community service outreach, and ways that they understand their own growth process as evangelical Christian emerging adults.

A total of twenty FIU alumni from the classes of 2009-2012 between the ages of 23 and 34 were interviewed in this study. The sample population of evangelical Christian FIU alumni was identified by the graduates' previous membership in oncampus Christian organizations, including Campus Bible Fellowship, InterVarsity, Cru, and the Wesley Organization.

Emerging adults in this study saw changes in their community life, prayer life, Scripture reading, and their views of theology, yet overall they maintained a strong commitment to their evangelical Christian worldviews. Findings suggest types of support that evangelical Christians in this sample seek during emerging adulthood. 


\section{TABLE OF CONTENTS}

CHAPTER

PAGE

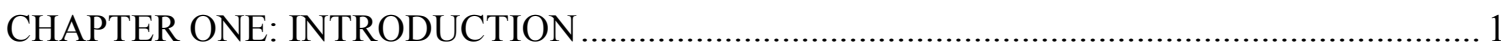

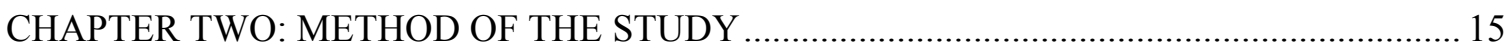

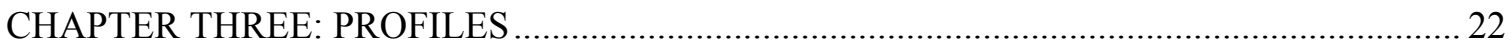

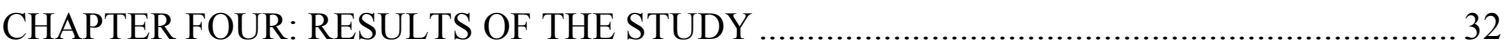

CHAPTER FIVE: DISCUSSION OF THE STUDY ………………………………………....... 51

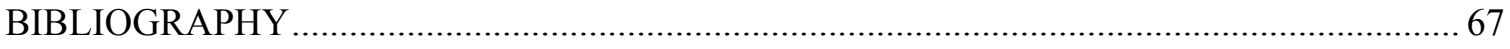

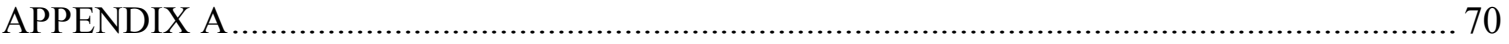




\section{CHAPTER ONE: INTRODUCTION}

Current societal trends among 18- to 29-year-old individuals in the United States - trends that include delayed marriage, frequent changes in career, and increasing levels of higher education - have led researchers to propose a new life stage between adolescence and young adulthood. This stage has recently been named "emerging adulthood." Jeffery Arnett, a pioneer in the field, describes emerging adulthood as "the new period that has opened up in the life course of people in industrialized societies during the past half-century, bridging adolescence and young adulthood" (Arnett 452). A number of other scholars, including Christian Smith, Robert Wuthnow and James Côté, bring attention to the same issue and examine it in the cultural context of American mass consumerism, individualism, and the information explosion, all of which in their view have had a major impact on identity formation. As a result of these recent trends, the personal tasks of identity exploration that were once central to development during adolescence (ending at age 18) have been delayed significantly into early adulthood (ages 18-29). In the decades after World War II, scholars like Erik Erikson $(1950,1968)$ and James Marcia (1966) proposed that identity exploration associated with fundamental choices related to love, vocation, and worldview formed the main developmental challenges of the teen years. In contrast, the newer research explores how in more recent decades this important phase of the life process has been delayed. It now constitutes the main set of challenges for individuals in the early adulthood years (ages 18-29).

This study focuses on a single subcategory of emerging adults: Protestant evangelical Christians in the post-college middle and later stages of the emerging adult 
transition. It specifically considers what is happening to their religious lives- their beliefs, emotions, and actions - as they experience emerging adulthood. According to recent studies of emerging adults, the general characteristics of religion among all emerging adults include: a decline in religious service participation, an increase in the individualization of religion, and an increase in skepticism regarding religious institutions. Additionally, some scholars claim there is strong evidence that childhood religious training in religion is left behind in this transitional phase of life; their beliefs are only weakly correlated with religious convictions in emerging adulthood (Arnett 459). These initial findings have appeared in broad surveys like the National Study of Youth and Religion (NSYR) conducted under the leadership of Christian Smith at the University of Notre Dame. Smith and his associates gathered data very widely from a broad population that is mainly Christian and of either Catholic or Protestant background, including both major and minor Protestant denominations. Studies of this kind are not just informative about their own subject. They also provide opportunities for additional research that can supplement and refine their broad efforts by focusing on specific subgroups, such as Protestant evangelicals, for whom religious concerns have been highly significant. While there have been others who have conducted research targeted on the religious beliefs of emerging adults, there has not yet been extensive in-depth research conducted within individual religious subgroups.

Protestant Christian evangelicals are among the most important of these subgroups. They are not only a noteworthy segment of the American population; they also have been very conscious of their identity as evangelicals. In their comprehensive 
research programs, scholars like Arnett and Smith do not specifically discuss evangelicals. They adopt more general categories and place evangelicals in them along with others. Arnett uses the term "Conservative" to broadly define more traditional Christians (30). For his research, which applies six categories to define the spectrum of different religious viewpoints, Christian Smith uses the same term, but also refers to an alternative term "Committed Traditionalist" (124). However, there are certain features of evangelicals that set them apart from others in this affinity group; they often consciously identify themselves as different from other conservative Christians - Catholics and other Protestants - with whom researchers associate them. And because they think of themselves as different, and stress certain beliefs and practices in unique ways, there is value in considering them separately. Also, apart from the issue of religious identity, there is the issue of the age cohort in the national research. Though multiple studies examine the spiritual lives of high school and college students, there is a dearth of research that specifically analyzes the spiritual lives of individuals in the years immediately following college graduation. These years make up the middle to later phase of emerging adulthood. These ages (23-29) have been seen as cultural milestones for full adulthood, when emerging adults expect to marry or be married, start families, and settle into their careers. Therefore, the post-college phase of early adulthood leading up to that turning point is significant.

This study focuses on both of these lacunae — evangelicals after college — by interviewing and surveying twenty FIU alumni from the classes of 2009-2012 who fall within the subset of post-college emerging adults in the U.S. who identify themselves as Protestant evangelical Christians. The sample population of evangelical Christian FIU 
alumni was identified by the graduates' previous membership in on-campus Christian organizations, including Campus Bible Fellowship, InterVarsity, Cru, and the Wesley organization. These groups share certain typical religious characteristics, which include a focus on spreading their faith to others, an acceptance of biblical authority, and a strong emphasis on individual salvation, often through reference to a "conversion" experience. They do not attach their identity to any specific Protestant denomination, though they tend to be connected most often to churches that have been known historically as Baptist congregations, Bible Churches, or independent fellowships. Sometimes they also form a distinctive subgroup within the historic confessional denominations -Presbyterians, Reformed, and Methodists - that put a special emphasis on these evangelical beliefs and practices.

Among the alumni whose names have been furnished by the various campus organizations, twenty were selected randomly and asked to participate voluntarily. This research project thus examines the question: How are the spiritual lives of evangelical Christian FIU graduates affected or altered during the two to four years following their college graduation? Further questions focus on community, relationships, vocation, and whether or not the participants view themselves as emerging adults. Questions include: Since graduation, have you found a Christian community that supports your religious/spiritual beliefs, offers you satisfying fellowship, and/or offers you opportunities for Christian service? If so, describe that community or communities (i.e. church, friends that share your beliefs, volunteer organizations)? Has your prayer or devotional life changed since your FIU graduation (in the past one to four years)? How 
has it changed? Has the amount of Scripture that you read changed since your FIU graduation? Have the ways in which you approach reading Scripture changed since your graduation? This study takes into account how post-graduate plans, or lack of defined plans, may correlate with various aspects of the students' spiritual lives.

In addition to individual circumstances, I consider how broad cultural trends may affect emerging adult views of spirituality and identity. Current trends consist of delayed marriage, globalization, employment and career challenges, and the information explosion (Wuthnow 20). Since a number of studies have shown that involvement in religious organizations tends to increase when emerging adults have children, I also look for differences in responses among individuals who are parents (Wuthnow 57). Economic concerns are also considered. In Transitions to Adulthood in A Changing Economy: No Work, No Family, No Future?, for example, Alan Booth, Ann Crouter and Michael Shanahan specifically cite alarming economic unsettlement as a main factor affecting this phase of life. Because of the scarcity of appropriate jobs, many emerging adults switch jobs frequently, prolong their residence with parents, and choose to cohabitate rather than marry. This study examines changes in spirituality as they may be affected by these cultural, social, and economic trends.

In these 20 mini-case studies I look for patterns in prayer life/devotion, community service outreach, and mentorship, as well as in the ways these evangelical Christian emerging adults understand their own growth process. I also make some comparisons of my results to the results of studies on college youth and the existing studies of emerging adults, to determine whether these members of the evangelical 
Christian campus organizations share or do not share characteristics of the wider emerging adult identity.

Evangelical Affiliation. According to the Pew Research Center, evangelicals constitute a significant percentage of the United States population-more than 25\% (Luis). If they are combined with historically black churches, many of which share the evangelical perspective, then they make up nearly half of all American Christians, who comprise nearly $80 \%$ of all individuals in the United States. Mark Noll, a leading figure in the study of American evangelical Christianity, concedes that it can be difficult to measure the number of evangelicals because there is a considerable degree of variety in understandings of the word. Therefore, he uses three main strategies for estimating the number of evangelicals in the US: (1) Determining how many people share the characteristic beliefs of evangelicals (i.e. biblical authority and conversion story); (2) Counting the number of people attending churches and denominations that have a strong connection to the historic evangelical movement; (3) Assessing how many people choose the term "evangelical" to describe their personal beliefs and convictions. The most useful of these strategies for this study is the first: defining "evangelical" in terms of certain characteristic beliefs, including their beliefs about what things they should practice. The existing research indicates that emerging adults are very loose about denominational affiliations and identities. They are not as likely to use the term "evangelical" to define themselves as they are to refer to certain beliefs they have about the Bible, a conversion experience, or their mission to spread Christian faith to others. So for the purposes of this study, the term evangelical most closely aligns with the first of Noll's three criteria in 
how evangelicals are surveyed. The organizations to which these interviewees belonged during their time at FIU share these common beliefs and associated practices.

Some further comments on the use of the term "evangelical" may be helpful. In America evangelicals show certain features of belief that stretch across various Protestant denominations. In American Evangelical Christianity: An Introduction Noll refers to another scholar of evangelicalism, British historian David Bebbington, who "has identified the key ingredients of evangelicalism as conversionism (an emphasis on the "new birth" as a life-changing experience of God), biblicalism (a reliance on the Bible as the ultimate religious authority), activism (a concern for sharing the faith) and crucicentrism (a focus on Christ's redeeming work on the cross, usually pictured as the only way of salvation)" (13). Accordingly, for this study, I determined that the best way to locate individuals of this kind was to focus on FIU alumni who were associated with one of the following FIU student organizations, all of which express in differing degrees these four features of evangelicalism. These organizations include: Campus Bible Fellowship, InterVarsity, Cru, and The Wesley Foundation. Although these alumni are associated with organizations that have an evangelical affiliation, I acknowledge, as stated above, that some interviewed graduates within the study may not choose to describe themselves as evangelical, nor do they necessarily believe that that word fully describes their religious convictions. It needs to be accepted that any individual's personal beliefs may vary in certain ways from the criteria provided here. But in general, Cru, Campus Bible Fellowship (CBF), InterVarsity, and the Wesley organization offer the 
most useful way of initially identifying the evangelicals because these organizations do converge on the ideas of conversionism, biblicalism, activism, and crucicentrism.

Cru. Founded in 1951 by Bill and Vonette Bright, Cru is an international organization with locations in 191 countries. Originally named "Campus Crusade for Christ," Cru's mission exhibits a distinctly evangelical profile. The organization's mission - to "win, build, and send Christ-centered multiplying disciples who launch spiritual movements"reflects hallmarks of conversionism, biblicalism, crucicentrism, and activism ("Cru”). Cru's stated purpose is to help "fulfill the Great Commission" which coincides with characteristic evangelical stress on activism as stated in Matthew 28:19-20, the "great commandment" of missions, in which Jesus instructs his disciples to "go and make disciples of every nation" ("Cru”). This strongly evangelical perspective of Cru manifests itself in world-wide endeavors to convert non-Christians to Christianity.

Campus Bible Fellowship (CBF). In 1965, Pastor Hal Miller of Iowa Falls, Iowa started CBF with the support of the organization Mid-Baptist Missions. The idea grew, and CBF now has locations throughout the United States and in multiple other countries. Miller saw $\mathrm{CBF}$ as a type of mission to college campuses that reflects the four features of the evangelical affiliation. Similar to Cru, for example, $\mathrm{CBF}$ also proclaims its activist mission "to fulfill the Great Commission to 'make disciples' given in Matthew 28:19, 20" ("Campus Bible Fellowship"). Additionally, CBF's website clearly shows the organization's emphasis on Bible study and conversionism, which is highlighted in its members' salvation stories. 
InterVarsity Christian Fellowship/USA (InterVarsity). InterVarsity originated in 1877 at the University of Cambridge, England. Students of the University formed the group as a way "to pray, to study and to witness to fellow students" ("InterVarsity"). Gradually the movement spread across the United Kingdom and among the country's European and American neighbors. Today there are over 1,000 InterVarsity staff members ministering to more than 34,000 students in the U.S. The guiding principles of the organization include the authority of the Bible and the profession of Jesus as the Savior of the world. Evangelical characteristics of activism and conversionism are also evident in the organization's core commitment to "live out the gospel with love and boldness, calling people to repentance, faith and new life in Jesus Christ" ("InterVarsity").

Florida International University-Miami Dade College Wesley Foundation (Wesley). As at other institutions of higher education, this Wesley foundation was created to minister to FIU and Miami Dade Community College students through community nights, Bible studies and service outreach projects. Rooted in the Methodist tradition, the evangelical features of the foundation's perspective can be found in statements such as "Jesus...our Lord and Savior, whose life, death and resurrection save us...calls us into a new way of life" (FIU MDC Wesley). In addition to this crucicentrism of Wesley, the organization's core values emphasize the authority of the Bible. Wesley also stresses the importance of grace and community among its values.

Literature Review. Because emerging adulthood is a relatively new area of research, there are lacunae that I would like to address as explained previously: specifically, a focus on the immediate post-college stage of emerging adulthood, and on emerging adults who 
have maintained specifically evangelical, rather than a more broadly Protestant, identification through college graduation. The major studies do a very good job of providing a broad overview of religious attitudes and quantitative analysis of different religious typologies. For example, in various works on the topic, such as Emerging Adulthood: The Winding Road from the Late Teens through the Twenties, Jeffery Arnett examines major trends and identity aspects of emerging adults ages 20-29 throughout the United States. Religion is one of these aspects, along with work, love, family, marriage, and sources of meaning. Arnett found the religious views of the emerging adults he interviewed to be highly varied, and his work led him to divide his respondents into four religious categories: Agnostic/atheist (22\%); Deist (28\%); Liberal Believer (27\%); Conservative Believer (23\%) (Arnett 169).

These designations are informative, but they are naturally limited to broad types that are defined in general terms. The group Arnett designates as "Conservative," is where evangelicals generally fall in his typology. But as was noted above, that typology also would include many Catholic emerging adults, and many who associate themselves with more confessional Protestants—Lutherans, Reformed, Presbyterians, and otherswho do not stress the four leading characteristics of evangelicals. They may show them partially, or in moderate ways, but that is not where these traditions put their main emphasis. In addition, some researchers do not distinguish between early and middlelater phases of emerging adulthood: that is, college and post-college cohorts. I think it is also useful to separate these two groups, and see what differences there may be. Graduation from college is a significant transition point in emerging adult life. Just as 
elementary and secondary schools provide a social structure that shapes students while they learn, colleges and universities also provide a social structure—often even more so when students live on campus. When they graduate, they transition out of that structure; it is a turning point when for the first time since age five or six, individuals in our society end their formal education as controlled by institutions professionally focused on learning. Also, the post-college transition is especially relevant because of the significant increase in the number of Americans who now pursue higher education.

With a different focus from Arnett, who devotes portions of his emerging adulthood research, but not the full range of his studies, to religious issues, Christian Smith and colleagues have studied in depth the spiritual lives of teenagers and younger emerging adults (ages 18-23) through the National Study of Youth and Religion (NSYR). This is a major long-term longitudinal study. It is being conducted in waves, starting with the early teen years of the respondents. In this ambitious project Smith and his team have, at different points over the past ten years, interviewed 122 individuals regarding their religious and spiritual lives. An initial phone survey was followed in a second phase by extended interviews. The telephone and personal interviews were conducted when the participants were teenagers (ages 13-17). A third wave of research, as Smith describes it, was published in 2008. For this phase, Smith interviewed the same individuals and examined their religious and spiritual lives as younger emerging adults (ages 18-23), dividing the religious findings into six religious categories: (1) "Committed Traditionalist;" (2) "Selective Adherent;" (3) "Spiritually Open;" (4) "Religiously Indifferent;" (5) "Religiously Disconnected;" (6) "Irreligious." 
My sample's affiliation (evangelical Protestant) falls within Smith's "Committed Traditionalist" category, where "personal commitment to faith is a significant part of their identities and they [conservative traditionalists] are at least somewhat regularly involved in some religious group" (Smith 167). However, as with Arnett's grouping, the "Committed Traditionalist" category includes more than evangelicals; traditional Catholics and various confessional Protestants fall within its borders. Also, in terms of the age group, the most recent research by Smith's team ends with an analysis of the spiritual lives of emerging adults up to age 23; his longitudinal survey has not yet reached beyond the phase of development that occurs in college years. The post-college group will make up Smith's fourth collection of interviews, which will follow this same cohort of participants into middle and later emerging adulthood (ages 23-29). While Smith and his colleagues prepare to publish these findings, I am focusing on the same middle-tolater age group, but more specifically on evangelicals. Although the main intent of my research is not comparative, it may be able to give some insight on whether defining the target group as "evangelicals" might lead to any differences from the broader categories used by Arnett and Smith. Also, the results of the interviews I have completed with these evangelicals in the post-college stage of emerging adulthood could possibly be used for comparison with some aspects of the next wave of Smith's study, when his sample group has come into the same age cohort as mine.

Aside from the plan of the NSYR as it goes forward, there is limited research that specifically focuses in depth on the religious and spiritual lives of emerging adults between the ages of 23 and 29: the period of their transition into post-college years. This 
study will aid in bridging the gap in research and help to evaluate the religious lives of one religiously defined group of college graduates in this stage. This study restricts itself to the cohort of immediate post-college graduates who were members of evangelical Christian student organizations, and attempts to determine what are the main characteristics of their emerging adult religious experiences. Where more context and other insights can be gained, I also refer to: the results of the studies of the religious/ethical lives of college and post-college students in general; the results that Smith and Arnett find using their categories of "Committed Traditionalist/Conservative Protestant;" and the findings in these and other surveys about emerging adults in the early (college) phase or the full emerging adult cohort that provide background that helps understand the post-college transition of evangelicals in the phase that my research is focused on.

There is one research project of a type similar to my project, but its focus is on a different age group. Kara Powell at the Fuller Youth Institute in Pasadena, California has started the Sticky Faith/College Transition Project, a longitudinal study that follows 500 high school graduates (mostly from evangelical Christian backgrounds) as they transition into post-high school life in their first three years of college. While the Sticky Faith Project explores an earlier type of transition (from high school graduation through college years) for emerging adults ages 17-21, its focus is on the same evangelical subgroup that I am targeting. My research could possibly be expanded in order to complement hers as a future path of research. It may be able to provide a pilot study of further comparisons that can be made between the transition of teenagers with the 
evangelical affiliation out of high school at ages 17-21 and the transition of evangelical emerging adults out of college into the older, post-college age group. 


\section{CHAPTER TWO: METHOD OF THE STUDY}

This study has taken place in Miami, Florida. The data organized here were collected from graduates of Florida International University (FIU). FIU had an enrollment of 31,589 undergraduate students in 2009, and by 2012 that number had increased to a total of 35,875 . Of the students enrolled during this four-year time frame, an average of 22,175 described themselves as Hispanic, 4,087 described themselves as White, 4,007 described themselves as Black, and 25 described themselves as Pacific Islander. FIU had a higher female than male population in the years between 2009 and 2012, with 18,686 students identifying as female and 15,061 as male. Most students at FIU are Florida residents, with an average of 31,560 undergraduate students from the years 2009-2012 identifying as Florida residents and 2,194 identifying as non-residents.

FIU alumni from the years between 2009 and 2012 who participated in an oncampus evangelical Christian organization comprised the population for this study. The sampling frame for this study consisted of membership lists of FIU on-campus evangelical Christian organizations from the years 2009 to 2012. In order to gain access to this population, I conducted online searches to find on-campus evangelical Christian organizations at FIU's Council for Student Organizations website. Additionally, I discovered evangelical Christian clubs and groups by visiting the FIU Club Fair during the first week of the 2013 fall semester. The completed list included the following organizations: Campus Bible Fellowship, Champions Plus, Christians on Campus, Cru, Disciples on Campus, InterVarsity, Sisters in Spirit, and the Wesley organization. Some organizations, such as InterVarsity and Campus Bible Fellowship are international in 
scope, while other organizations, such as Christians on Campus, have developed at the local level as a result of FIU student leadership.

Once the list of organizations was compiled, the designated head of the group was contacted through email or phone call. In these emails and phone calls, I explained the purpose of the proposed study, the interview process and confidentiality measures. I then requested membership lists of students from that leader's organization who would fit the criteria (graduated from FIU between 2009-2012 and belonged in some way to the respective group). Many of the leaders asked to meet me in person to learn more about the research study before providing lists of members. Although many of the selected organizations showed an eagerness to participate in the project, groups such as Champions Plus were too recently developed to provide recommendations that fit my study's criteria. Ultimately, Campus Bible Fellowship, InterVarsity, Cru, and Wesley provided the largest number of potential participants. In efforts to interview alumni who ranged in their participation and commitment among the various groups, I requested student membership lists from the years to 2009 to 2012. In some cases, such as with InterVarsity, member names were available through public information online. Once I compiled the list of InterVarsity names, the Religious Studies Department Secretary was able to look up and provide me with each student's graduation date and contact information. In the cases of CBF, Cru and the Wesley organization, these lists were not available; therefore the sampling frame was affected. In the case of CBF, Cru and the Wesley organization, then, the participant lists were assembled from the recollection of the group leader or through collaboration with past group leaders. 
From the names gleaned from these four aforementioned groups, I compiled the various organizations' participants' names and placed them in a secure spreadsheet. The total number of potential interviewees equaled 69. The division of potential participants was not equal; CBF yielded 23 names, InterVarsity provided 12, Cru included 13, and Wesley furnished 21.

After obtaining International Review Board approval to conduct a semi-structured interview with each alumnus/a individually, I began the initial outreach to my population, using systemic random sampling. I randomly selected 20 alumni and marked this selection in the spreadsheet. I sent emails to this sample describing the research study, including the details of the informed consent, and requesting a response. The email explained that an affirmative response signified consent to the terms of the study.

From the initial email, I received four affirmative responses. Of these four respondents, three met the criteria for the study. Two emails were returned because of incorrect or obsolete email addresses. If the selected alumni did not respond to the email or if they did not have a provided email address, they were contacted through phone call. This process was repeated with random sampling from the original list until a total of 20 alumni voluntarily had consented to participate in the study.

I conducted the 20 interviews for this study either in person or over the phone with each participant individually. Participants were read the informed consent either in the initial phone call or at the beginning of the interview in cases where scheduling was completed through email. Before each interview, the participants were sent a 
confirmation email with a closed-form questionnaire to be filled out and returned before the interview. If a participant was unable to complete the questionnaire before the interview, the survey was completed during the scheduled interview time. I conducted inperson interviews in the FIU Economics Department conference room or at my place of residence in the case of phone interviews. Responses were recorded through audio file and through notes taken in a Word file. These notes and the audio files were kept locked and confidential on secure servers.

Measures. My study included a questionnaire and interview. Participants were asked to respond to 52 questions in total: a 38 question closed-form questionnaire along with 14 open-ended interview questions (found in Appendix A). These questions draw from the works of Arnett, Smith, and Wuthnow. In the study, $25 \%$ of the questionnaire items originate from Arnett's "A Congregation of One" study and Smith's third wave of National Study of Youth and Religion (NSYR) research. The questionnaire contains questions regarding religious affiliation, employment, and feelings about reaching adulthood. The interview questions begin with a focus on community and proceed to explorations of religious practices, family, church and theology. These questions ask participants to describe their communities during college and their current communities. The survey for this study used both open- and closed-form questions to explore the leading issue: How are the spiritual lives of evangelical Christian FIU graduates affected or altered during the two to four years following their college graduation? Additional questions include: Since graduation, have you found a Christian community that supports your religious/spiritual beliefs, offers you satisfying fellowship, and/or offers you 
opportunities for Christian service? Has your prayer life changed since your FIU graduation (in the past one to four years)? How has it changed? Has the amount of Scripture that you read changed since your FIU graduation? Have the ways in which you approach reading Scripture changed since your graduation?

Coding categories for each interview question were created from reading through the interviews and noting common themes. Data was collected through documents, and then transferred to spreadsheets. Each participant was assigned a random number for the data set that corresponded to his or her questionnaire and interview responses.

Religion, belief, faith, spirituality are terms laden with various connotations. For this survey, I chose operational definitions to describe the following key terms: "faith," "spirituality," and "belief." "Faith" refers to a "way of finding coherence in and giving meaning to the multiple forces and relations that make up our lives" (Fowler 22). I use Fowler's definition of "belief" as "conscious intellectual agreement with particular doctrines or ideologies" and Fowler's account of "religion" as "beliefs and practices of a collective group of people over a period of time." Finally, Mayhew's definition of "spirituality" is used throughout this study; Mayhew defines spirituality as "the human attempt to make sense of the self in connection to and with the external world" (15).

Participants. The participants were 20 individuals (10 females; 10 males). All participants, ages 23 to 28 (with one outlier, age 34), graduated from FIU's various undergraduate programs between the years 2009 and 2012. Within this sample, all participants self-identified as "Christian" in response to the question of religious 
affiliation. "Non-denominational" was the most common response for the thirteen participants who responded to the question of religious denomination. Forty percent of the participants had been involved with more than one on-campus Christian organization. Twelve participants had been involved with Cru, eight had been engaged with InterVarsity, and seven had participated in Campus Bible Fellowship. Although The Wesley Foundation, like the other campus organizations, provided a membership list of names, the potential participants either failed to meet the criterion for the study (year of graduation), or did not consent to participate (see Fig. 1). Because participants marked all the groups to which they belonged, the total number in Fig. 1 exceeds 20 participants.

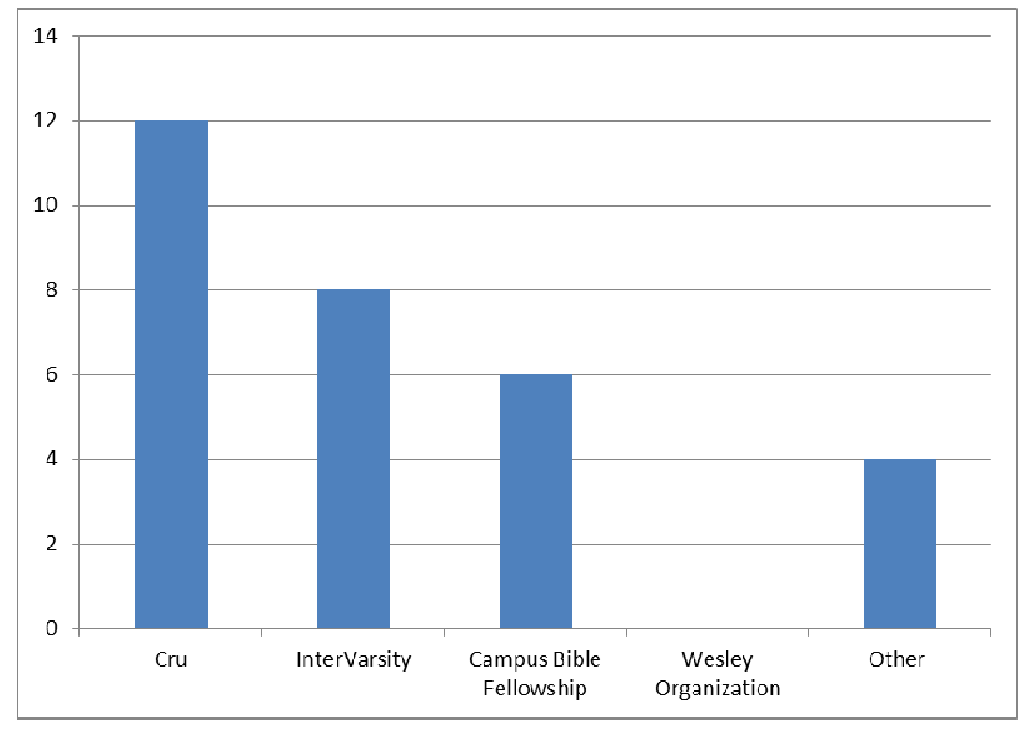

Fig. 1. Participant Representation in Campus Organizations.

Nine of the twenty participants graduated in 2012, three in 2011, three in 2010, and five in 2009. Over half of the participants were single and six (30\%) were married. Three of the married participants had at least one child. In my study, half of the 
participants identified as "Black/African-American" followed by six identifying as "Hispanic/Latino(a)" (see Fig. 2). The categories "White/Caucasian," "AsianAmerican," and "Other" had equal numbers of three participants. Because participants marked all the racial categories to which they belonged, the total number of participants in Fig. 2 exceeds 20 individuals. Of the three individuals who marked "Other," one identified as "Haitian-American" and two as "Caribbean-American."

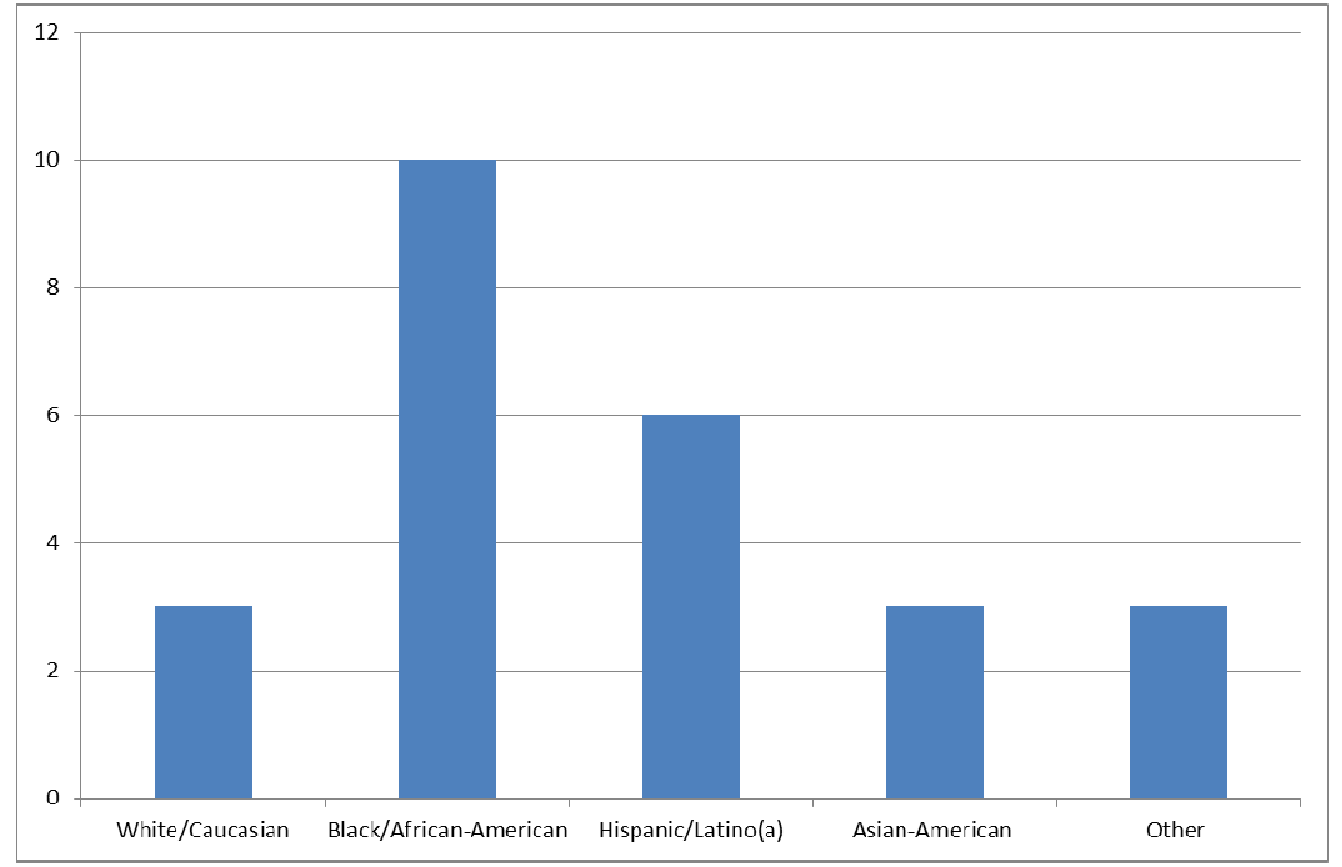

Fig. 2. Racial Identification of Participants. 


\section{CHAPTER THREE: PROFILES}

One way to understand the survey research in this project is to start with a typology and personal profiles. First, what kind of person is an emerging adult in the most general understanding of that term? How does he or she act? What are his or her concerns? Second what kind of person is a religiously conservative emerging adult? What are her or his major concerns? How does she or he think and act in addressing them? How does he or she differ from the first type — the general emerging adult? Finally, and as the center of this study, what kind of person is an evangelical emerging adult? What are her or his concerns? How does she or he think and act? And how is the evangelical adult similar to, or different from, the other two types? In this chapter I draw upon current research to make a profile for the first two of these types; I then rely on my interviews to give two brief portraits of actual evangelical emerging adults based on my interviews conducted with FIU graduates.

The Typical Emerging Adult. Jeffrey Arnett and others have discussed the main characteristics that define emerging adults and explain the personality features that they display. He singles out five things in particular to consider. Emerging adulthood is, first

of all, an age of identity exploration. It is a period when most people in the age-interval between 18 and 29 try out various possibilities that will be very important for their longer-term adult lives. They see life at this stage as intentionally experimental; so they think in a temporary way about careers, about relationships, marriage, family, and philosophy of life, or world-view. For these reasons, emerging adulthood is also a period of instability. Major life decisions need to be made at some point, but they do not need to 
be made immediately. And because they are important and determine so much about the future, it is important not to make decisions quickly. Once decisions are made, life does become more stable, but it also becomes more fixed. It is hard to turn back and start again; there is a "point of no return," so it is better to live with the instability before getting to that point.

During this period of instability, life is also self-focused. Emerging adults usually do not say so openly, but they assume that in this phase of their lives, it really is "all about me." The most important job is to understand themselves, discover who they really are, who they want as a family or close friends, and who they wish to be when they work and when they have leisure. Fourth, emerging adulthood is a time of feeling in-between. They are no longer adolescents, but also they are not yet adults. They must deal with unsettlement because that is a main element of "in-between-ness." They know finality is coming when adulthood arrives, and they know it will arrive, but in the meantime they must cope with the transition from what they were to what they decide that they will be for the next half-century until they reach old age. Finally, this period in life is an age of possibilities, so for most (but not all) emerging adults it is a time of optimism and excitement. The focus is on the future, and the future is like a candy store; it has many choices, and almost all of them seem to be very tasty.

Arnett also says that in this period of life three self-oriented things are most important to emerging adults: taking responsibility for yourself; making independent decisions; and becoming financially independent. This struggle for independence offers the excitement of making good choices and moving out from the shadow of parents' 
supervision; but it also has the risk of mistaken choices. For some emerging adults the choices made are short-sighted and can be self-destructive. Risky behaviors bring on alcohol and substance addictions, create unwanted pregnancies, or lead to HIV/AIDS or other STDs. These things also often have lifelong consequences as well. It is in emerging adulthood that younger Americans face these personal risks and opportunities most directly.

The Emerging Adult and Religion: The Typical "Conservative Believer." Scholars of emerging adulthood present different systems for distinguishing the diverse perspectives on religion that are adopted by emerging adults. One category in those systems is the Conservative, or Committed Traditionalist Christian. Christian Smith locates this group as the most traditionally religious among six different categories of younger adults that extend all the way to openly irreligious. Conservative, or traditionalist, emerging adults claim to have a strong religious faith, which they actively practice. Their faith guides their moral life and is important to their personal identity. They usually participate in some form of religious group, and are usually of either white or black Protestant or Mormon background. They focus on inward devotion more than on social or political causes. The typical conservative believer attends church with some consistency, though not necessarily every week. He or she is the type of person that participates in a Bible Study group, and makes the effort to read the Bible privately also. Prayer is also consistently a part of the conservative lifestyle, as is the effort personally to experience God's presence as near and involved in personal decisions and activities. The heart of religious life is the individual in relation to God; people should always beware that 
institutional, formal religion as practiced in organized churches does not become a danger to inner, spontaneous spiritual life.

In terms of doctrinal or philosophical beliefs, acceptance of orthodox Christian theology is an important foundation for the conservative believer. Belief in God as Creator and as the Trinity of Father, Son, and Holy Spirit is assumed. The Christian story of the Old and New Covenant-Creation, Fall, Redemption-- is the central theme of history. The Son of God assumed human form, as Jesus Christ, in human history to die for the sins of humanity. Those who accept his sacrifice will be forgiven and will join him at the Second Coming to pass through the Final Judgment with all of mankind and live in Heaven with Christ afterward and for all of eternity.

Moral life and moral values are guided by these theological beliefs. Religiously conservative emerging adults recognize that in moral behavior they are different from most others their age. In romantic relationships, the ideal is to reserve sexual experiences only for marriage. A clear majority believe abortion is wrong. Alcohol should be viewed as risking an addiction; drugs and other strongly addictive substances are unacceptable, and for most, homosexual behavior also violates the principles of Biblical morality. Among conservative emerging adults these morally questionable behaviors do not necessarily require the harsh judgment that such people are destined for Hell. That decision is left to God. Conservative believers, finally, realize they are a minority (consisting of approximately 15\%) of the total emerging adult population. 
Evangelical Emerging Adults: Two Profiles. With the above profiles as background, short profiles of two of the emerging adults, Vanessa and Nick who were interviewed for my study can now be drawn to offer some insight into the evangelical personality, and how evangelical attitudes in some ways share, but in other ways differ from, the types described above.

Vanessa. Vanessa was my second interview, and happened to be my first phone interview. She spoke openly and energetically about her experiences since graduating from FIU with degrees International Relations and Political Science in 2011. Vanessa was minimally involved in Cru, but also found community at FIU through her Christian Sorority. She states, "That's where I became a Christian" as a junior at FIU. She could point to this moment as a conversion-like experience.

Like many of the participants in my sample, Vanessa often took on both official and unofficial leadership roles when it came to her Christian faith. Not only did she lead Bible studies for her sorority, she also explained that she was the one who would encourage her friends and sorority sisters to attend church and on-campus religious organizations. Vanessa viewed Cru as a supplement to the Bible Studies that she would lead with her sorority sisters. "Once I became a Christian, I started looking for groups on campus to join. I met a lot of cool people at Cru. And soon after encouraged my friends to join" she explained.

Similar to the other emerging adults in my study, Vanessa has stayed committed to the Christian faith throughout the post-college transition. 
Vanessa states that in the two years since graduating, she has only recently found a community. In her years since graduation she began a practice that many emerging adults exercise: church hopping. She would go to one church one weekend, then another church the next week. She states that she wasn't sure what she was looking for. She attended a number of "mega" churches such as Metro Life Church that have large numbers of attendants. She now attends Hollywood Community Church and recently decided she wants to become a member. According to Vanessa, the people are inviting, the atmosphere is personable and the service is more traditional. As a teacher, she notes that she likes the emphasis the church places on serving the students and community outreach. "I didn't want a commercial place, a place that didn't feel like a church, megachurch with TVs at every corner," said Vanessa, "It's...feeling like a business that I want to avoid. I want a church to feel like home." Vanessa's influence has encouraged her boyfriend, along with a good friend from her FIU sorority and her friend's boyfriend to attend Hollywood Community Church regularly as well. Through becoming a member, she hopes to further her participation in this church.

Along with valuing community, Vanessa expresses the desire for increased leadership roles and mentoring within her church community. Vanessa suggested that churches could better attract the young adult age group "if leaders reached out to mentor people my age [and] give them opportunities to learn about how to be involved." Church leaders could also improve their outreach to her age group "by giving them responsibilities within the church." 
Like many of the evangelical emerging adult participants in my study, Vanessa saw increases in her prayer life, increases in her Scripture reading and changes in her commitment to Christian theological concepts since her undergraduate career at FIU. Similar to other respondents, Vanessa found that being exposed to different worldviews and religious perspectives in the workplace triggered in her a change in commitment to theological concepts. In contrast to some of other evangelical emerging adults in my sample, Vanessa differs in her response to these other religious perspectives. Other participants felt strengthened in their own Christian beliefs when presented with differing worldviews. Vanessa, though, explained that although she felt committed to the Christian faith, she questioned aspects of her beliefs as a result of being exposed to other religious or non-religious individuals. She stated, "I'm challenged by the non-believers around me — my boyfriend and my friend's boyfriend especially. I still question, 'How can it be that other religions might not receive eternal salvation?' I struggle with the malevolent side of God."

Vanessa found these doubts, challenges and questions to be direct results of her post-college transition. As one would find in the typical emerging adult typology, Vanessa described the uncertainty during this stage of life. "It directly relates to the transition," she responded when asked about the uncertainty; "I ask for guidance with the decisions that came with this uncertain period." Despite her concerns, the uncertainties of emerging adulthood "made her draw closer" to her God overall.

Nick. As my eighteenth interviewee, Nick fit the evangelical emerging adult typology that I had been developing throughout the interview process. Nick, a 2012 graduate, was 
actively involved in multiple on-campus organizations, had a strong dependence on God, and came from a religious family.

Similar to Vanessa's desire for mentoring, Nick believed that church leaders and members could create more satisfying community by interacting with members of different generations and practicing more acceptance of generational differences. $\mathrm{He}$ explains that each generation can learn to benefit from the preferences of the other generation:

I see the problem as two-fold: 1. Young adults ignore the old. 2. The older generation ignores the young ones. I think both are wrong because you need to look at all these groups. God's Word doesn't change. For the older generation, they can accept that social media is all around, and contemporary music can glorify God. And young people can understand that hymns can edify God. This generation needs to accept what's already there, and have to appreciate what's already there. We need to learn from each other, but shouldn't change content.

Nick's viewpoint suggests that if the church is founded on sound theology that seeks the Word of God, generational differences could be used to improve a church community.

Nick also felt deepened and challenged in his understanding of Christian theology during the post-college transition. Nick explains that being removed from his FIU community challenged him to rely on God and to deepen his theological understandings. 
He states, "I was challenged by everything from finding a new church to finding a new job. At FIU I relied on the Bible studies and I wasn't prepared to leave. And when I got here [to graduate school in Tennessee] I felt alone. I was "spoiled" at FIU." That created the challenge that deepened his "walk with God."

Like the majority of the emerging adults in my study, at the time of the interview Nick strongly disagreed with the survey question about feelings of depression during this stage of life. And like Nick, none of my other participants agreed with the statement asserting feelings of depression. This contrasts with what Arnett finds among the general emerging adult population. He finds that about one third of the typical emerging adults agree that they have feelings of depression. It is true that though none of my participants affirmed having feelings of depression at the time of the interview, a couple, including Nick, did describe past bouts of depression.

Although there were other participants that mentioned past episodes of depression at marked points during their post-college transitions, Nick was the only participant to describe in detail his experiences of depression and treatment. Nick's story in particular gives an enlightening aspect to the evangelical emerging adult perspective regarding depression and mental health. Nick graduated from FIU in 2012 and within months began his move to Tennessee to begin graduate school in the fall of 2012. During this transition he not only moved to a completely new city, but also ended a serious relationship with his girlfriend of three and a half years. He explains, "When I came here, my relationship fell apart. She fell away from the Lord when I moved to Tennessee. A lot of that affected me in my transition. I had all these things fall apart." 
Nick first turned to alcohol for help and then to psychological counseling. He found both remedies fruitless. The drinking left him feeling empty and the counselor listened, but failed to give him an action plan. "I also saw some pastors, elders, but nothing worked until I went to Scripture," Nick said. Turning to the Bible was the only remedy for his depression. "I started reading the book of Job and had the most conviction in all of my life. Nothing else could provide that hope. Only the Word of God with the encouragement of family and friends."

Nick's experience with depression supports the idea that spirituality can serve as an essential coping skill during the post-college transition. Nick's story shows one way in which the evangelical emerging adult subgroup may use prayer, Scripture reading, and community outreach as coping mechanisms during times of depression. High levels of prayer, Scripture readings and satisfying community are associated with lower feelings of depression. Nick's experience also causes me to question how the evangelicals in my sample report their responses to depression. A number of participants reported having feelings of depression at one point or another during their post-college transition, yet none responded affirmatively to having feelings of depression at the time of the interview. For evangelical emerging adults, is it congruent to have a committed faith in God and feelings of depression? It could be that in the evangelical subculture, as in others, there are religious reservations about disclosing, or even acknowledging, the topic of depression. Exploring whether or not evangelical Christians find it plausible to have both a strong faith and a depressive disorder is an area of my study worthy of more research. 


\section{CHAPTER FOUR: RESULTS OF THE STUDY}

Looking at the results of this study should begin with the category of "emerging adulthood" itself. The majority of the young evangelical adults in my survey agree on the characteristics of instability and the feeling of being "in between" that affect their lives in the ways that scholarly literature describes. When asked if they felt that they had reached adulthood, nine of the sample group answered "yes" while eleven answered "in some ways Yes/in some ways No." These findings do not show a large difference from the responses on surveys of the general population. Arnett's Clark University Poll of 1,029 also shows an almost even 50-50 split on this question among the emerging adults he surveyed. This was true up until the very last years — ages 26-29—when Arnett found that a clear majority began to identify themselves as adults without the qualification "in some ways Yes/in some ways No."

In terms of questions focused on identity exploration and life satisfaction, the responses of evangelical Christians were also largely similar to those found in the religiously diverse general population. My interviewees were asked to mark their agreement with seven statements using a Likert scale analyzing mental health, change, and satisfaction within this life stage. Seventeen of the twenty participants marked that they agreed (either somewhat or strongly) with the statement: "This time of my life is fun and exciting." Eighteen participants marked that they agreed that "this time of my life is full of changes." When asked to respond to "I am satisfied with my life," all but one participant marked "agree." In response to the statement about having a great deal of freedom in this stage of their lives, there were two who disagreed and two who were 
neutral, but all others were in agreement. The statement about having a great deal of freedom in this stage found just two who disagreed, two neutral, and sixteen (80\%) who agreed.

On the other hand, thirteen of the twenty interviewees $(65 \%)$ felt that this is a stressful time of life. Twelve of my participants (60\%) felt that their lives are full of uncertainty. The research of both Smith and Arnett indicates that emerging adulthood is a phase of life marked by positives of optimism and excitement, but also by the negatives of stress and uncertainty. My research shows that most evangelical post-college emerging adults definitely share these mixed attitudes. Their responses are almost unanimous in reporting the positives of fun and excitement, while smaller numbers, but still majorities, reported stress and uncertainty. These results also seem to show that the completion of college does not lead to any significant reduction in the number of respondents reporting a stressful time of life. This pattern may suggest that the causes of stress go beyond academic concerns about getting good grade-point averages and making progress to graduation and involve other issues of personal life. Those issues continue to affect young adults beyond the completion of college and the time of stress over academics. Regarding mental health, seven of the participants (35\%) agreed that they "often feel anxious." Yet none of these evangelicals agreed with the statement that they "often feel depressed," and only two marked "neutral" for this question. Similarly, none of the participants agreed with the statement "I often feel that my life is not going well," with four marking "neutral" in response to this prompt. 
These results seem to differ significantly from those that emerge from research on the general emerging adult population. In responses Arnett received to these three questions focusing on mental health, he found a significantly higher percentage of emerging adults who have experienced these negative emotions. In the Clark University Poll of Emerging Adults, Arnett found that $56 \%$ of the 1,029 emerging adults ages 18 to 29 stated that they "often feel anxious; $32 \%$ often feel depressed, and $30 \%$ often feel that life is not going well." There is a $21 \%$ divergence between the evangelicals in my study who reported feeling anxious (35\%), and the finding of 56\% in Arnett's study. This difference may not be that significant. Anxiety can be interpreted as something good, associated with anticipating a good outcome, as well as concern over something bad. A more important finding of my study is that $0 \%$ reported feeling often depressed or that life is not going well (though rather small percentages $-10 \%$ and $20 \%$ respectively—did respond "neutral"). These figures are very different from Arnett's research. My results may indicate an association between positive attitudes (or lack of negative attitudes) and evangelical religious commitments. I think this association should possibly be studied further because there is another study from outside of North America conducted with a non-Christian religious tradition that also seems to show this association.

Recognizing how caution that should be used in citing another religion in another society, I find that my results seem to converge with the findings of Gnanaprakash, who has found that post-college students who scored high on spirituality measures are better able to adapt and cope with stress. In his study, "Spirituality and Resilience among PostGraduate University Students," which was conducted in India, Gnanaprakash surveyed 
100 university post-graduate students, ages 20 years to 25 years, through random sampling. Correlations were found between those students who scored on The Daily Spiritual Experience Scale (DSES), designed to measure "spiritual experiences as expressed in the daily lives of people," and the Cognitive Emotion Regulation Questionnaire (CERQ), which assessed emotion regulation. Highly spiritual students relied on "transformational coping strategies such as acceptance, positive refocusing, positive reappraisal, which act to cognitively transform a potentially negative events into a growth producing experience" (394).

Gnanaprakash's study sheds light (though from a different cultural community) on religious coping strategies and stress within emerging adulthood. Although his research was conducted in India and used certain measures of his own type, the results of his study on these negative emotions and positive responses are mostly similar to my study's findings. The age of the students studied and the focus on university graduates both provide points of comparison between Gnanaprakash's Asian emerging adult sample and my study of American college recent graduates. Also, both studies focus specifically on religious factors involved in the development of coping strategies. My study finds that practicing evangelical Christian individuals who depend on their Christian faith tend to feel anxieties of other emerging adults, but those whom I have interviewed do not indicate feelings of depression or conclude that life is not going well. Their faith seems to provide them with coping strategies that transform negative events into positives for them, just as Hindu beliefs seem to provide coping strategies for the post-college transition in India. 
Community Life. In addition to questions that focused on mental health and reaching adulthood, my participants were asked questions that focused on changes in their communities. On the subject of community life during their undergraduate years, the participants I surveyed responded with positive descriptions overall. Responses to the prompt "Describe the community/community groups that you were a part of during college" were coded for emotional and descriptive language. The descriptive responses explain these communities as "Bible studies," "worship groups" or "fellowship" groups. William, a graduate from 2009 who was involved with various on campus groups, provides insight into the distinctions between $\mathrm{CBF}$ and Cru. He states, "CBF was a group that was very in-depth. The missionary families [who led] the group had good relationships with the other people in the group, and we met throughout the week. A big piece was...how do we have a biblical [view] vs. the world view? It was a more mature study." William elaborates, "Cru was more about sharing the gospel and evangelism. We would hang out together more often. We'd hang out every day, meeting and encouraging each other." William stressed that CBF offered a more structured discussion of how to apply the teachings of the Bible to help live according to Scripture's guidelines rather than the "world's," or secular society's, guidelines.

In personal and emotional terms, participants responded with only positive descriptions, such as: "caring," "authentic," "nonjudgmental." "Friendship" was the most prevalent theme within this set of responses, with eight out of the thirteen emotional respondents describing their communities as places where they cultivated deep relationships. Fifteen participants (75\%) stated that they were highly involved in their 
respective Christian organizations during their college years; three responded that they were moderately involved and only two responded as minimally involved. Some of the participants who were highly involved participated in multiple on-campus Christian organizations. William, who served on the board and as president of CBF, explains, "I used both groups, [Cru and $\mathrm{CBF}$ ], to work together. I'd invite people from one group to another so that there wasn't this clash between bible groups." The participants in my study attended their religious organization's social events, meetings, or gatherings quite regularly. Eight participants attended at least twice a week. Eleven of the twenty participants attended at least weekly. Only one participant marked that she attended once every two weeks.

The majority of participants (16 of the 20 individuals) responded affirmatively to the question "Since graduation, have you found Christian communities that support your religious/spiritual beliefs, offer you satisfying fellowship and offer you opportunities for Christian service?" This percentage of affirmatives - $75 \%$ in college and $80 \%$ after college - are very similar in these two cases; so there was essentially no change in the level of success in finding communities of support, even though college life provided this support very conveniently through campus organizations. After college, young adults do not have that same convenience, but it appears that it did not affect success in finding support communities.

In general, the research on emerging adults and religion shows they are sometimes critical of churches and institutional religion, yet in my survey, the majority of my participants stated that in one way or another they found their new community 
through their respective churches. The churches that they describe refer to either the church attended in college, or a new church that they found since graduation. Twelve of these fifteen found their church community through a church friend or relative. Three found their new community through "church shopping." A common practice among emerging adults, church shopping "involves tinkering with one's religious loyalties by looking for a congregation to attend, presumably one in which a person will settle and become a regular member" (Wuthnow 114). Additionally, four of the fifteen still considered their college relationships with friends and members of their on-campus Christian organization to constitute their post-graduate communities.

Who has not found satisfying community? Four participants $(20 \%)$ responded that they have not found a replacement community. They cite recent changes in location, busy schedules, graduate work, family responsibilities, or failure to search for churches as reasons why they have not found a satisfying community. Within this group, two participants belonged to InterVarsity, one belonged to $\mathrm{CBF}$, and one belonged to Cru. Although these individuals did not find a community post-college, they described their undergraduate communities very positively. The majority were moderately to highly involved in their on-campus Christian communities. One these participants was highly involved in her organization, two were moderately involved, and one was minimally involved.

Sarah, a 2009 graduate and mother of two who was minimally involved in CBF, stated that familial responsibilities, church preferences, and her husband's differing religious beliefs are the reasons why she has not found a church community. She 
explains, "I haven't found [a church] specifically because of time constraints. My

husband does not like to go that often and I have not found a church that I like. Some are too noisy and some are too calm during worship."

Sarah has not found a worship style that she likes or pastors that preach the sound theology she desires. She describes one particular situation where she found the speaker at the church to stray from biblical teachings. She stated, "One sermon I went to was titled 'God Wants to Take Snapchats with You,' and I saw this as promoting something that shouldn't be used for biblical purposes." Sarah did not mind that the preacher used a metaphor about technology to describe an aspect of God's relationship with humans, but she became troubled with the preacher's choice of technology: Snapchats. Snapchat, a popular photo-messaging mobile application ("app") designed for individuals ages 13 and older, allows users to send photos, drawings, videos, graphics and other materials to a select recipient or group of recipients for a designated time limit (1-10 seconds). Once the time limit expires, the material is no longer available. Although Snapchat can be used in a responsible way, the app has an association with sexting, sexual harassment, and pornography. Comparing God's desires to relate with humans to an app like Snapchat created serious concern for Sarah. Sarah summarizes this problem explaining, "There's so much focus on other stuff rather than focus on the Word of God."

A subgroup of four participants from my sample was currently in graduate school. Although Nick and Michael, two of these four graduate students, felt that they had found satisfying community as graduate students, Ariana and Nicole, the other half of the graduate student subgroup, felt differently. Both Ariana and Nicole explained that 
graduate school constraints have kept them from finding satisfying community since their undergraduate years. Nicole, a 2010 graduate now in law school in Miami, explained that she has found it difficult to be involved at church because of graduate school responsibilities and because the on-campus Christian organizations do not reach out to her age group. "I think that those organizations target undergraduates," Nicole explained. She stated, "I haven't seen them target the law school building. And that's where we live. It would take too much time to get involved. I still go to church but can't be as involved." These constraints have kept her from finding a community similar to InterVarsity's that she was a part of during her undergraduate years.

Similar to Nicole's reasoning, Ariana, a 2010 FIU alumna who is currently in graduate school for psychology, explains, "I have not found any [community] outside of church nor do I have time. My church does provide some community, but it's difficult because I am a graduate student and a commuter student. I live so far from school that I don't have time to stay there to socialize with friends in my classes."

Chris' story was one that most clearly showed signs of the emerging adulthood aspects of being a stage of "transition" with feelings of being "in-between" (Arnett). Chris recently moved back home to live with his mother in Fort Pierce. When asked to elaborate on why he feels he has not found satisfying community, he explains, "Fort Pierce is a small town so there aren't many options for community. Also, I'm in transition and not planning on staying in this area long-term." Chris has not found community in this new city, but explains that he has not actively searched for it either. 
Evangelical Emerging Adult Desire for Sound Theology. As much as they stressed a postgraduate worshipping and gathering community, the majority of participants in my study strongly emphasized the importance of sound theology and a serious intellectual community to their spiritual lives. When asked what kind of support in a community would be attractive to participants, 16 of the respondents $(80 \%)$ desired support related to "increasing theological understanding." Oliver, a 23-year-old participant, further explained this desire in his interview. When asked what types of community would be important to him, he stated, "For me, a community composed of people who think [and] people who take their faith seriously. People who take their faith seriously [and are] able to explain what the Christian faith is." Oliver stressed that he was searching for "less 'therapy group' and more 'teach what the church says'" in his church community. The strong interest that my participants showed in "serious faith" suggests something that presents a contrast with the research of the more widely based national surveys. Both Arnett and Smith observe that for a great many of the emerging adults they surveyed, religious concerns just did not draw strong attention. Instead of being seriously engaged, most emerging adults are casual about religious matters. But measuring by the accounts of most of these evangelicals, theology and faith are not for them not casual at all. They are looking for opportunities to become seriously engaged with issues relating to their faith.

Religious Practices. The next section of the interview explored changes in religious practices among my sample. Participants were asked to discuss changes in their prayer lives, reading of Scripture and church experience since graduation. All participants 
marked that change had occurred in their prayer lives. Although all interviewees could explain how and in what way the changes specifically in their own lives had occurred, there was no clear single trend that could be found in their explanations. The changes ranged from increased prayer or deeper prayer to less-focused or decreased prayer; in some cases it was a change to a more individual kind of prayer. When asked to elaborate on the reasons for these changes, four of the participants (20\%) stated that having a busier schedule, whether in graduate school or a full-time career, influenced their changes in prayer life. These four individuals explained that the uncertainty that comes with these changes in schedule, work and career had actually led them to pray more. Christina, a 26year-old respondent who was highly involved in InterVarsity and Campus Bible Fellowship, explained, "My praying has been more frequent. After I graduated college, I felt more tossed in the wind. So not having control forces me to pray."

Victor, a 24 year-old alumnus who was part of Cru, responded similarly to these obstacles during this new stage. "Graduation for me was a break," he said; "it was a time to be done with school to reconnect with God and to work. For the first 3 years [of college], I felt like I had no direction. Graduating with [a BA in] history gave me some direction and I was able to make my own decisions. But it wasn't until after graduation that I stopped and asked God for direction." Christina and Victor illustrate how some of the emerging adults in this study respond to the uncertainty and exploration encountered in this stage of life with prayer.

In regard to Scripture reading, fourteen participants (70\%) reported a change in the amount of Scripture that they read since graduating from FIU. Eight of these fourteen 
participants specified that the amount of Scripture that they read changed by increasing. Three said that their Scripture reading had decreased, and the remaining three did not specify. Among the three students who showed a decrease in Scripture reading, we see an association between community structure and encouraged Scripture reading. The three who said their Scripture reading had decreased cited busy schedules and being away from a structured community as reasons for this decrease. Among the eight who saw an increase in their Scripture reading, they explain that the reason for this increase is a continued desire for spiritual maturity and for increased knowledge of Scripture as they develop their faith. Many participants respond that they "desire to keep learning" and "desire to know God." Therefore, participants did not see graduation as the trigger for this change in Scripture reading. Participants who saw an increase in their Scripture reading attributed this change to spiritual progression.

Further, seventeen interviewees noticed a change in their approach to reading Scripture. One trend among respondents regarding this change centered on the use of supplementary materials in their Scripture reading. Seven out of the twenty-35\% of the interviewees - described how they now incorporate works by other Christian authors as they read Scripture. One participant stated, "Now I do a lot of self-study, incorporating the works of N.T. Wright [and] St. Augustine." Another explained that he now incorporates the use of the Hebrew and Greek biblical texts to delve deeper into the original meanings of some of the biblical texts. Five of the seven participants who cited their use of study guides and works by Christian authors explained that their reason for doing so was a desire to grow spiritually. When asked to describe the reason for this 
change, the participants spoke of this new approach to Scripture as a next step in their spiritual journeys and as a way to mature in their understanding of Christian doctrine. Only one participant marked that she had not seen a change in her amount of Scripture reading nor in her approach to Scripture. She attributed this consistency to her continued involvement with the same bible study that she had been a part of during her undergraduate years.

When asked about changes in attendance at religious services and meetings, those interviewed did not highlight any sharp change from the college to post-college years. Over half of the participants stated that they attend these events more than once a week, and all except one attend church at least once a month, despite the fact that five have not yet found a church community. Of the number of individuals who chose to respond to questions of attendance, eight participants stated that their attendance has not changed, while four saw an increase and seven said it had decreased. This decrease was due to situational factors, including graduate school, family responsibility, and busy schedules. It is evident that a very high percentage of evangelical emerging adults (95\%) in my study continue to remain participants in church life on a regular basis, even if their attendance is not weekly.

Participants were asked who/what they looked to for strength. All respondents described themselves as being moderately to highly dependent on God for strength. In addition to God, some respondents included influential Christian friends or family members. This result seems to differ sharply from Smith's survey of emerging adults in 2003 and again in 2008. Between 2003 and 2008, his survey showed a sharp decline in 
the sense of closeness to God-from $48 \%$ to $35 \%$ in the interval of five years. There was no evidence of such a small percentage among the post-college emerging evangelical adults responding in this survey on their sense of dependence on God. The number of those who responded affirmatively to this statement seems to show a reversal of their attitude, not only from the percentage (35\%) Smith found in 2008, but even from the original higher percentage (48\%) he reported of his participants in 2003. Another explanation of this difference could be that evangelical experiences are in this respect different from that of other, non-evangelical Conservative Protestants. My study cannot give an explanation of the difference, but it does indicate that this issue could be analyzed further to see whether these different results can be confirmed and what the reason for the difference is.

Family Life. In addition to questions that explored changes in religious practices, participants were asked to describe their families and homes. According to Arnett, one trend that accompanies the delayed marital age among emerging adults is an increase in the number of individuals who live with parents or return to live with their parents well into their 20s. My interview questions examined this trend with a number of questions exploring the circumstance of prolonged parental support. Of the twenty participants, five owned or rented a house with a spouse; seven individuals reported that they were living in a rented apartment or house with roommates; and eight resided with parents. Twelve respondents stated that they pay their own bills, rent and/or mortgage. Participants in these mini-case studies describe their parents and families as very supportive in multiple ways. When asked if their parents showed support during the transition out of college, all 
but two participants responded affirmatively. All but one interviewee explained that their parents were involved in some positive way through the transition. When asked if they still receive help from their parents, nine individuals answered affirmatively, explaining that they receive support or some form of support (e.g., medical insurance) from their parents. When asked generally in what different ways parents had been supportive, the most prevalent answers included emotional, spiritual, and financial support. Housing and food costs were included in participant descriptions of financial support. Fourteen participants explained that parent support or lack of support affected their spiritual transition from college.

In many studies of emerging adulthood, researchers explain that delayed marriage is one among many societal trends that influence the postponed transition to adulthood. The emerging adults in my study reflect this trend toward delayed marriage. Of my selected sample, 13 participants $(65 \%)$ were single or in a committed dating relationship. The number of years married among the seven married participants ranged from nine years to less than one month. Participants in dating and married relationships were asked how that relationship affected religious affiliations, church attendance and spiritual life in general. Although two participants stated that the relationship had not affected any of these practices, five of the seven married respondents stated that they have grown spiritually because of their relationship. When asked about how the relationship would affect religious and spiritual life in the next decade, seven out of ten respondents answered that they expected the relationship to help their spiritual life progress or help them "grow in faith." A significant point to notice is that all participants who were in a 
dating, engaged or married relationship were dating someone who shared the interviewee's faith to a certain degree (i.e. identified as a Christian).

Church Life. When asked about changes in church life, the majority of individuals in this study found a difference in their post-graduate experiences of church life when compared to their church experience before graduation. Although there is no common theme among participants to explain their change in experience, the most common responses include switching to a new church, the addition of a Young Adult's group, and an increased focus on the theology of the church. Relating to this issue, participants were also asked "What kinds of support do you look for from a church community?" In answering this question, 17 out of the 20 participants mentioned "fellowship" or a place where people "know who you are." Oliver, a participant who explained that he had found community through the church he currently attends, describes why many emerging adults are attracted to his church. He explains, "The community keeps them. There are not a lot of old people. There are young couples with families." When asked to explain the types of support the church offers the young adults, he described community groups which are composed of "bible study, prayer, and outreach." The church's outreach includes raising money for organizations such as World Vision, an Evangelical Christian humanitarian aid organization, and social outreach, such as joining a run club in the downtown Miami area. Walter, a 2009 graduate, looks for "small groups, discipling programs, and a regular service that [members of the church community] encourage you to be a part of." Themes of family, acceptance, and spiritual support were prevalent in my participants' discussions of church life. 
Questions in this section also asked, "If you have a congregation, explain how your congregation meets or could better meet those needs" and "What are some specific ways in which church leaders could better meet the needs of your age group? These questions were coded for descriptions that included "mentoring" and "intergenerational involvement." When looking at these two questions together, close to fifty percent of the interviewees requested "mentoring" (9 out of the 20 participants). The term "mentoring" refers to experienced, theologically knowledgeable adults, typically from an older generation, advising emerging adults individually or through workshops on religious beliefs. The emerging adults interviewed in this study viewed mentoring as a way to explore various options within their own religious worldview, career path, and relationships. One participant, Samuel, explained mentoring as "an opportunity to learn from another adult in the church who has already been through these changes [to] give their take on how to be involved in the church, what it's like to raise a family, [and] why they chose their career."

To other participants, mentoring provided a gateway toward more committed involvement in the church. One individual explained that mentoring would help him feel involved in the church and help him to take on more responsibility in the church. Ana, another participant, viewed mentoring as something that could be accomplished through a more structured environment. Ana stated that, "One thing our church could do better would be providing more guidance on career choices and relationships...things that churches don't typically talk about so openly." She explained further that having the 
church provide these workshops would not only help guide her with important decisions regarding these topics, but provide a desired Christian perspective on these issues.

Changes in Theology. The last section of the interview asked participants about changes in their understanding of Christian theology and theological concepts. When asked "How has your understanding of Christian theology changed, deepened, or been challenged by your experience since graduation?" all twenty participants responded that their views on Christian theology had changed in some way. The most prevalent theme among the reasons for this change was "openness to new viewpoints." Six participants described various ways that their view of Christian theology had changed through their newfound openness to religions other than Christianity, to controversial issues such as abortion, and to differing views within Christianity (i.e. Calvinism vs. Arminianism). Many participants explained that joining the workforce after graduation exposed them to differing views among co-workers. Another participant explained that the nature of her career allowed her to be open to new perspectives. Although she had studied homelessness as a topic in her undergraduate social work major, working alongside homeless individuals caused Megan to be open to new perspectives on the reasons for these issues. She states that these experiences challenged her preexisting beliefs about these issues and asked her to reevaluate theological concepts in her response to such issues.

Of the six participants who voiced their openness to new viewpoints, only one participant, Vanessa, who was mentioned earlier in my study, described this openness as a challenge to her Christian faith. While the other five participants viewed interacting 
with individuals of different religions as ways to strengthen their Christian commitment, Vanessa explained that being open to new viewpoints has tested her Christian faith. As she learns more about other religions of the world, Vanessa has been challenged in her understanding of the Christian view of salvation. She explains that although a main tenet of evangelical Christianity states that one must believe in Jesus as Savior, she struggles with this concept as she is exposed to differing worldviews in her post-graduate career and social life. She attributes this doubt to moving away from her FIU community, but also states that her boyfriend's doubts and questions about this "universalist" issue have triggered her questions.

Although Vanessa specifically stated graduation as a main cause for this change, the majority of participants state that these changes in theology were a result of situational changes in their community lives and a maturation of their faith. 


\section{CHAPTER FIVE: DISCUSSION OF THE STUDY}

The intention of this study has been to gain a better understanding of young evangelical Christians as a subgroup of young Americans who belong to the newly formed sociological category called "emerging adulthood."

The in-depth interviews conducted with the participants in this survey show that evangelical Christian young adults face the same need to manage transition and instability as all other emerging adults do. They know that they need to cope with an "inbetween" phase in their life course. They struggle with making big decisions about work and marriage, and about family, community, and meaning. They know that the postcollege transition is a phase of identity exploration, along with anxiety about the future. The main challenge for them, like all other emerging adults, is becoming independent emotionally, intellectually, and financially. My research shows that although they know they must become independent and that my participants have anxiety about the future, my sample of evangelicals also know they are not alone. The majority feel that they have resources and they know how to take advantage of them. There are people and communities, and there is a system of beliefs that they can depend on during this stage of life when they are trying to become independent. That is a real strength for evangelical emerging adults. The literature on emerging adulthood shows that young people from other religious traditions, or from non-religious backgrounds, often do not have these resources. Many emerging adults find themselves floating in a culture of relativity and judgments, where many less religious or non-religious friends and acquaintances feel pushed to say almost anything is acceptable for anyone; all behaviors are permissible as 
long as "no harm" is imposed on anyone else. Many of the evangelicals I surveyed believe differently. Most of them had structures they trusted and could lean onchurches, communities of friends, and parents. Many participants in my sample also sought opportunities to find these additional forms of support, such as through a relationship with a mentor. They also have the Bible and Bible studies, and some very strong traditional Christian doctrines. These factors provide them with many resources for stability while they face instability. In different ways all of these resources are very beneficial in such a time of transition. In my opinion, these resources help to explain why even though evangelical Christians in this group have anxiety, like all other groups, none of them said they were depressed, or felt that their life had no meaning.

A clear belief system focused on personal faith in God or Jesus Christ seems to be the foundation of those resources. My study reveals that among this sample of evangelical Christian individuals, most participants strongly maintained their commitments to their evangelical Christian beliefs, and in some cases those beliefs became deeper than before. All participants described themselves with various combinations of the phrases "religious," "spiritual" and "having a relationship" with God or Jesus Christ. Also, all emerging adults in this study described themselves as dependent on God, with answers ranging from "moderately dependent" to "very dependent." Both the questionnaire items and the responses in the course of individual interviews showed clear commitments on the part of emerging adults to Christian faith, doctrine, and "living a life for God." Their faith was emotionally grounded, not just intellectually agreed to. 
For most of my participants, this emotionally grounded faith was also associated with a long-term perspective that went back to earlier phases of life. There seems to be a close relationship between the strength of these emerging adults' current beliefs and the strength of the religious dimension of life in their families during their childhood and adolescence. Regarding the religiosity and spirituality of their families of origin, fifteen of the twenty participants in my study described the religious dimension found in their families in the years when they were growing up as "strong" or "very strong." The findings show that those fifteen individuals in this study who came from families with a strong religious dimension also held strong evangelical Christian commitments in emerging adulthood. Some religious features of their upbringing, such as denomination, differed in some cases from the emerging adult's current practices, but all of these fifteen participants reported strong religious convictions on the part of one parent or more and cited attending church as a child or adolescent.

Among the significant national studies conducted in emerging adulthood research, there are conflicting conclusions about the connection between emerging adult religiosity and the strength of the religious dimension during childhood. Arnett's findings differ in several noteworthy ways from my results, while Smith's findings generally align with most of my results. While the measures and the ages of the participants differed among the studies of Arnett, Smith and my own, there are components of each study where one may draw cautious comparisons. I find that different results from these studies of the association between childhood religious experience and emerging adult religious convictions to be noteworthy of discussion. Arnett finds that there is a missing link 
between childhood religious exposure and the religious beliefs of emerging adults. Though there is a connection between adolescent religious belief and childhood religious exposure, Arnett finds that this connection does not exist among emerging adults. His research found that "about $60 \%$ of emerging adults had "high exposure" to religious training in childhood, meaning their parents took them to religious services on a regular and frequent basis" (173). About 20\% had "moderate exposure" where parents took them to religious gatherings once in a while without much commitment, and another $20 \%$ had "low exposure," meaning parents "rarely or never took them to religious services" (173).

When Arnett assessed these levels of early religious exposure against current religious beliefs, he found a clear disconnection. He says that in "statistical analyses, there was no relationship between exposure to religious training in childhood and any aspect of their religious beliefs as emerging adults—not to their current classification as agnostic/atheist, deist, liberal believer, or conservative believer; not to...the importance of religion in their daily lives; not to their belief that God or a higher power guides their lives..." (174). Arnett does say that he found some cases of emerging adult beliefs reflecting those of parents, but the examples are too rare to show up in a statistical analysis.

Arnett's study is extensive because his questions have a sample of over 1,000 emerging adults that he divides into the categories of agnostic/atheist, deist, liberal believer, or conservative believer (13). He stresses that the lack of connection between childhood training and emerging adult belief applies to all of these four categories, including emerging adults who are conservative believers. But that is a major 
disagreement with what my research on evangelicals shows. As was stated, my study's sample of evangelicals most closely aligns with the views of Arnett's conservative believer category. But in my interviews these evangelicals show a strong relationship between the childhood training that they received from their religiously sincere parents and their own faith at the present time. Therefore, Arnett's statement about no connection is puzzling, especially since he emphasizes his point so strongly. As was stated above, evangelicals are one type of conservative believer with their own traits, so they are not the same as other conservatives in Arnett's group. For that reason, the associations that emerge within my study between the childhood and emerging adult religious dimensions could show a point where these evangelicals' experience diverges from others in the conservative believer category. It is also possible that the reason is because my group (ages 23-34) is an older age cohort than Arnett's group (ages 18-29). But I am doubtful about that. From the results of my interviews with my participants, I cannot find a good way to explain this difference. In the future, I recommend repeating my study with a larger sample of evangelical Christian emerging adults to see if there is a statistically significant confirmation of the association that I found, but Arnett did not. I have to accept Arnett's much bigger sample of participants interviewed, but I still am not able to explain why the results of my interviews with post-college emerging evangelicals are so different from Arnett's.

Another reason for being unclear is that Smith's research does align more with my own findings. Smith's NSYR research and my study both look at frequency of religious service attendance and frequency of personal prayer. These measures are 
beneficial in measuring the strength of religiosity as they are "tried and tested" within the sociology of religion, as well as being commonly accepted in America as indicators reflecting high levels of religiosity. They examine both public practices of faith and more "subjective experiential dimensions" of religion (Smith 212). Smith's analysis compares the results of the NSYR Wave 1 data (conducted when participants were 13-17) and the Wave 3 results (of emerging adults ages 18-23). He finds that "among first wave (labeled W1) variables, having had highly religious parents and frequent religious service attendance during the teenage years are most strongly associated with more religious service attendance, greater importance of faith, and more frequent prayer during emerging adulthood" (214). Smith also finds correlations between the strength of parents' religious practices during the teenage years and outward and inward expressions of high religious faith during the emerging adult years. Whereas Arnett finds no significant relationship between religious exposure during childhood, Smith finds moderately strong to strong correlations between religious practices and the strength of the individual's parents' religious convictions during emerging adulthood. Therefore, according to Smith, strong parental religion associates with strong religion of emerging adults ages 18-23.

According to my study strong family religiosity associates with strong religious conviction among post-college emerging adults, ages 23-34. My sample reveals that this strong religious dimension of family is carried not only until age 23, as Smith shows, but throughout the later emerging adult years of my sample of evangelical Christian individuals. My study does not account for individuals who may have abandoned their family's religious traditions during their high school years, but then returned to their 
families' religious traditions at age 23 . But many emerging adults in my sample do state how the religious dimension was strong in their families when they were growing up and explain how parents, siblings and extended family serve as spiritual supports through the transition to post-college life. Luis states that his family has been "110 percent supportive" through his transition out of college. Acknowledging their support through encouragement as well as financial and spiritual support, Luis describes that his parents have "helped me be thankful and not take things for granted." His parents' religious convictions, especially those of his mother, were important. He stresses that they "helped me thank God and take a view of gratitude." Luis and other participants who responded similarly suggest that parents who offer spiritual support during the post-college transition are associated with high religious service attendance and high dependence on God for emerging adults. It is hard to see how this kind of support was not an extension of the religious training that was received in childhood. And this leads to the strong likelihood that there was an association between these variables that Arnett does not find.

Mentoring. One significant element emerging from my study is the importance of "mentoring" in religious life. Close to fifty percent of the interviewees ( 9 out of the 20 participants) cited mentoring in response to the questions "What are the main kinds of support you look for from a church community?" and "What are some specific ways in which church leaders could better connect with your age group?" These questions were coded for descriptions that included "mentoring" and "intergenerational involvement." The term "mentoring" refers to experienced, theologically knowledgeable adults, 
typically from an older generation, mentoring or advising emerging adults individually or through workshops on religious beliefs.

This idea of mentoring has been studied further in Sharon Daloz Parks' theory of faith development, which provides a useful framework for understanding its appeal. Drawing from the works of other faith developmental theorists, such as Fowler, as well as developmental psychologists Piaget, Erikson, Kohlberg, Gilligan, Perry and Kegan, Parks has assessed the role of mentoring in religion in her books The Critical Years: Young Adults and the Search for Meaning, Faith and Commitment (1986) and Big Questions, Worthy Dreams: Mentoring Young Adults in Their Search for Meaning, Purpose, and Faith (2000). Parks stresses the importance of the young adulthood stage in the process of faith development, which has three aspects: cognition, dependence, and community. In early adulthood cognition changes from the earlier "authority-bound" and "unqualified relativism" phases of adolescence to "probing commitments."

The dependence of individuals also moves from the "dependent/counterdependent" and "fragile inner dependence" of adolescence and young adulthood to the "confident inner dependence" of early adulthood, where individuals are able to express confidently their own sense of self and their faith. In a similar way the third aspect of development shows changes from the "conventional community" and "diffuse community" of earlier and later adolescence to a "mentoring community" of young adulthood, which becomes an essential place that "offers hospitality to the potential emerging adult self, poses challenging questions and provides access to worthy dreams of 
self and world" (Parks 121). From there, the emerging adult progresses into the stage of a "self-selected class or group" that expands the mentoring community.

For young adults in the probing commitment phase, with varying levels of inner dependence, mentoring communities provide an accepting space for individuals to explore their career ambitions, religious beliefs, and attitudes toward choosing a lifelong partner. In my study, nine out of twenty individuals desired mentoring from their religious communities. Parks' perspective offers an explanation as to the wider significance of these findings. She states "for the emerging adult, community finds its most powerful form in a mentoring community" (120). As emerging adults transition from adolescence's authority-bound communities, they seek a mentoring community that "ignites the transforming power for the emerging adult era" (121). This spark is found through the individual taking ownership of his or her own faith through reassessing his or her own understanding of trust and power. Parks states that during emerging adulthood "a viable network of belonging is key" (121).This network, composed of mentoring figures and a social group that shares the individuals' own beliefs, allows for emerging adults to "feel recognized as both who they are and who they are yet becoming" as they address concerns ranging from their career ambitions to their perspectives on the meaning of life (121).

Parks' emphasis on the importance of these communities, as well as my study's participants' search for this type of communal need that they want to be filled, highlights a deeper challenge within the stage of emerging adulthood. Emerging adulthood is described as a stage of self-focus, but also one where institutional support has been 
removed (in the form of the school structure that is now gone). Parks describes the support of mentoring institutions during the emerging adult post-undergraduate years as "notably lacking." Nine participants of my study—nearly half of the number-have clearly noticed this void and called for mentoring relationships as a way to improve their Christian communities during the post college transition.

\section{CONCLUSION}

My study explores the question: How are the spiritual lives of evangelical Christian FIU graduates affected or altered during the two to four years following their college graduation? I conclude that the emerging adults in my study saw changes in their community life, prayer life, Scripture reading, and their views of theology, yet they maintained a strong overall commitment to their evangelical Christian worldviews. All the individuals in the study spoke very highly of their on-campus Christian organization, many recounting stories of the deep friendships established through these communities. Sixteen individuals found new communities through churches.

Many of the interviewees expressed the view that churches were able to fulfill their need for community, while other participants felt these needs were not being fully met. They felt their new church communities needed to offer more social activities, such as Bible study groups, recreational activities, or mentoring opportunities.

Four of the twenty participants explained that they had not found satisfying community through the post-college transition. One participant cited family responsibilities and difficulties finding a church that provided the worship style and 
theological messages she desired. Two of these participants explained that graduate school commitments have made it difficult for them to find community. One participant found it difficult to seek community during what he explained as a temporary move back home to his small hometown.

The satisfaction of those who find community and frustration of those who do not, or who do not find enough of it, are significant. Emerging adulthood can be "all about me," to some degree, as Arnett says. But the experience of the evangelicals in my study shows that the "me" also needs others. Community is important for evangelicals in emerging adult life.

Community support is also related to the importance of theology. This study reveals that a systematic set of beliefs that are firmly held is a critical resource in helping evangelicals with the post-college transition and the uncertainty of their lives. To follow this strong system of evangelical theology, emerging adults also need to have group support of their beliefs, which they get support from communities. It is harder to have such firm beliefs if there is less of a community to surround the individual to support him or her. Although she was a minority of one, the aforementioned comments of Vanessa illustrate this point. She found that the more she encountered other non-Christian friends and acquaintances, the harder it was for her to believe that their beliefs were completely wrong. Vanessa had found supportive evangelical Christians in her post-college church community. Her situation brings to light the question of what might happen to the evangelical Christian emerging adults who did not have a strong support of a Christian community while encountering these differing religious worldviews in the post-college 
transition. Their evangelical faith has a high level of confidence; if that confidence starts to weaken, it is more of a threat to an evangelical who started from a firm belief system, than for an emerging adult from a liberal church or a non-religious family who never had the certainty before. For those people, who were always less certain or had fewer beliefs, losing confidence is not so personally traumatic. So if there is less community, it could be that especially for evangelicals, they will experience more uncertainty, and their faith will be likely to be more fragile and less of a resource. Either that or they must find a way to continue their commitment by finding a way to the kind of faith with flexibility that is a sign of maturity rather than one that is insecure.

Limitations. Limitations of the method in this study include a volunteer bias. Because gaining access to membership lists of individuals in the various on campus groups was limited to the names provided by leaders of each group, the participant lists were dependent on the recollection and discretion of the group's leaders. Although membership lists were requested from the years 2009-2012, only InterVarsity membership lists were secured. That membership list allowed for a more complete representation of individuals, from those who were rarely involved to those highly involved in the organization during their time at FIU. In the cases of Cru, Campus Bible Fellowship and The Wesley Foundation, it was not possible to determine whether the group leaders had solicited participant names. If members had volunteered their names to be added to the participant lists, this risks that the sampled population was mostly the students who were highly involved with the organization during their time at FIU. Additionally, if the group leaders relied solely on their own memories of group members from the years 2009-2012, there 
is a high probability that selected alumni for the participant lists were those members who were recognized in the organization because of their involvement or continued contact with group participants.

For further research, gaining access to membership lists through a confidential and IRB-approved method would lead to a more complete picture of the post-college transition. As seen in the results, all alumni in this study have maintained their faith, showing continued church attendance, Scripture reading, prayer life, and dependence on God. With membership lists that would include students who were in the organization for limited amounts of time or were less involved, this study would be able to analyze distinctions that could possibly be traced to these variables.

Directions for Future Research. These case studies have provided me with an in-depth look into the changes these individuals experienced in their religious lives during their transition to their post-college years; though certain elements of this method of research provided important benefits, it would be best in future studies and new research to gain access to membership lists and interview a larger sample, so that the results better represent all the FIU alumni who were part of on-campus evangelical Christian organizations.

Some of the specific issues related to other studies also can be examined. As discussed before, my research leads to a different conclusion from Arnett about childhood training and emerging adult belief. And as also discussed future comparisons could be made with the results of the Sticky Faith Project, and especially with Smith's 
longitudinal National Study of Youth and Religion when results of his interviews with the emerging adults in my age group are published.

In addition, for further research it would be valuable to expand this study not only in sample size, but in population. I would like to research in particular the relationship between the post-college transition and students' geographical relationship to their school. Whether a person is an out-of-area student living away from home at a residential institution or attending as a local commuter student are variables that deserve to be explored. FIU has a high population of commuter students. Some of the individuals in my study who were local commuter students seemed surprised by some questions that considered graduation a critical transition. They stated that they do not view graduation as a major religious or emotional change in their lives; it is not accompanied by any move to a new location; it does not mark a dispersal of college friendships; and it is not a major change from school to work. About half way through our interview, one commuter student stated, "Graduation wasn't a defining moment." Some of these students also were already working full-time (or nearly that) throughout their college years. Even if they lived at home, they were otherwise responsible for their expenses (some paid rent). Some of them continued with the same employer after graduation, and are now eligible for promotions. In these cases, the participants' awareness of change seemed to be less intense than for participants who had moved a distance from home to attend college and were either remaining away from home, or were moving again to another location. A new study with questions that would try to address these issues specifically would be valuable. It would help determine how much religious change is affected by physical changes of location. 
Though many interviewees did acknowledge a change in their lives before and after graduation, the further exploration of the degree of change that locally based commuter students experience in comparison to other kinds of students could prove insightful. Comparing the experiences of FIU college graduates and those of other universities in the Miami area with mostly resident students (such as UM) would give a more complete and varied picture of this transition.

Another suggestion for future research is to narrow the range of graduation years within the criteria. In my study I interviewed FIU alumni from the years 2009-2012. The alumni who had been out of school since 2009 showed some differences in their responses from the 2012 graduates; they also showed a difference in their approach to answering the interview questions. The participants who had graduated in 2012 approached the interview questions as though they were currently experiencing the transition, while graduates from the year 2009 responded as though they were looking back on a completed transition. Though the 2009 alumni provided thorough analyses of their years since leaving FIU, for many participants it was difficult to grasp where to begin recounting the four years since graduation, and they had struggled at times to recall the transition from college life to their post-college experiences. Depending on the purpose of the next step of the study, I would either narrow the criteria to examining FIU alumni who graduated between 2012-2013 or to those who graduated between 20102011. This could be the beginning of an interesting longitudinal analysis similar to Smith's research design. 
My study comprises the first step of my methodological, sociological research of emerging adults, religion and the post-college transition. As I further this research, I would like to compare changes in the spirituality of emerging adults who do not attend college to participants in my sample. Additionally, I would also like to further investigate changes in spirituality, mental health and other aspects of emerging adult experiences during the post-college transition among minority groups. Because of the accessibility of researching college and university students, one criticism of emerging adult literature is the focus on the experiences of white, middle-class emerging adults and a lack of research among ethnic minority groups (Syed \& Mitchell 83). With the majority of FIU undergraduate students identifying as Hispanic/Latino(a), FIU provides an opportunity to study underrepresented perspectives among emerging adults. I hope to contribute to studies of ethnicity and emerging adulthood here in Miami before performing similar studies in other cultural contexts such as in Latin America, South America and Europe. 


\section{BIBLIOGRAPHY}

Adelson, Joseph. Handbook of Adolescent Psychology. New York: Wiley, 1980.

Arnett, Jeffrey Jensen. "Conceptions of the Transition to Adulthood: Perspectives from Adolescence to Midlife." Journal of Adult Development 8 (2001): 133-143.

Arnett, Jeffrey Jensen. Emerging Adulthood: The Winding Road from the Late Teens through the Twenties. New York: Oxford University Press, 2004.

Arnett, Jeffrey Jensen, and Jennifer Lynn Tanner. Emerging Adults in America: Coming of Age in the 21st Century. 1st ed. ed. Washington, DC: American Psychological Association, 2006.

Barry, Carolyn McNamara, and Larry J. Nelson. "The Role of Religion in the Transition to Adulthood or Young Emerging Adults." Journal of Youth and Adolescence 34.3 (2005): 245-55.

Booth, Alan, Ann C. Crouter, and Michael J. Shanahan. Transitions to Adulthood in a Changing Economy: No Work, No Family, No Future? Westport, Conn: Praeger, 1999.

Byrd, Nathan C., I.,II. "Narrative Discipleship: Guiding Emerging Adults to Connect the Dots of Life and Faith." Christian Education Journal 8 (2011): 244+.

Côté, James E. Arrested Adulthood: The Changing Nature of Maturity and Identity. New York: New York University Press, 2000.

"Campus Bible Fellowship International." Reaching University Students Through the Local Church. Baptist Mid-Missions, n.d. Web. 28 Oct. 2013.

"Cru : A Caring Community Passionate about Connecting People to Jesus Christ." Cru. N.p., n.d. Web. 28 Oct. 2014.

New York University Press, 2000. Erikson, Erik H. Identity and the Life Cycle. New York: Norton, 1980.

FIU MDC Wesley. N.p., n.d. Web. 28 Oct. 2013

Fowler, James W. Stages of Faith: The Psychology of Human Development and the Quest for Meaning. San Francisco: Harper \& Row, 1981.

Freitas, Donna. Sex and the Soul: Juggling Sexuality, Spirituality, Romance, and Religion on America's College Campuses. Oxford: Oxford University Press, 2008. 
Gnanaprakash, C. "Spirituality and Resilience among Post-Graduate University Students.” Journal of Health Management 15 (2013): 383-396.

Hoover, Kenneth R. The Future of Identity: Centennial Reflections on the Legacy of Erik Erikson. Lanham, Md: Lexington Books, 2004.

"InterVarsity Christian Fellowship/USA - Home - Intervarsity.org." InterVarsity Christian Fellowship/USA - Home - Intervarsity.org. N.p., n.d. Web. 28 Oct. 2013.

Konstam, Varda. Emerging and Young Adulthood: Multiple Perspectives, Diverse Narratives. New York, NY: Springer, 2007.

Marcia, James E. "Development and Validation of Ego-Identity Status." Journal of Personality and Social Psychology 3.5 (0500): 551.

Parks, Sharon D. Big Questions, Worthy Dreams: Mentoring Emerging Adults in Their Search for Meaning, Purpose, and Faith. San Francisco, CA: Jossey-Bass, 2011.

Powell, Kara E. Sticky Faith: Everyday Ideas to Build Lasting Faith in Your Kids. Grand Rapids: Zondervan, 2011.

Rockenbach, Alyssa B, and Matthew J. Mayhew. Spirituality in College Students' Lives: Translating Research into Practice. New York, NY: Routledge, 2013.

Smith, Christian, Kari M. Christoffersen, Hilary Davidson, and Patricia S. Herzog. Lost in Transition: The Dark Side of Emerging Adulthood. New York: Oxford University Press, 2011.

Smith, Christian, and Patricia Snell. Souls in Transition: The Religious and Spiritual Lives of Emerging Adults. New York; Oxford: Oxford University Press, 2009.

Sommers, Christina H. The War against Boys: How Misguided Policies Are Harming Our Young Men. New York: Simon \& Schuster, 2013.

Syed, Moin and Lauren L. Mitchell. "Race, Ethnicity, and Emerging Adulthood: Retrospect and Prospects." Emerging Adulthood 1 (2013): 83-95.

Tilton-Weaver, L. C., Vitunski, E. T., and Galambos, N. L. "Five Images of Maturity in Adolescence: What Does 'Grown Up' Mean?” Journal of Adolescence 24 (2001):143158.

"U.S. Religious Landscape Survey." Pew Research Centers Religion Public Life Project RSS. Ed. Lugo Luis. Pew Research Forum, February 2008. Web. 15 Nov. 2013. 
Wuthnow, Robert. After the Baby Boomers: How Twenty and Thirty-Somethings Are Shaping the Future of American Religion. Princeton: Princeton University Press, 2007. 


\section{APPENDIX A: POST-COLLEGE TRANSITION INTERVIEW QUESTIONS}

Name:

Gender:

Age:

Race:

Household income:

Religious affiliation (if any):

Religious denomination or tradition (if any):

Graduation Year:

Major:

Marital Status:

If married, for how many years?

Children? Yes/No

Are you employed now? Yes/No
If yes, how many?

If yes, full-time or part-time

Are you employed in the field that your degree/major prepared you for? Yes/No

How long after graduating undergraduate school did it take for you to find a job in your field?

a. 1 year or less b. 2 years c. 3 years d. 4 years e. 5 or more years

Do you see yourself in this same job in five years?

a. Yes b. No c. Maybe

How do you feel about that?

a. Very Satisfied b. Satisfied b. Neutral c. Dissatisfied d. Very Dissatisfied

With which Christian campus organization were you affiliated? 
When you were a student at FIU, how many times did you attend your campus organizations' activities (e.g. social gatherings, Bible studies, etc.)?

Describe your participation in the organization. Were you highly involved? Moderately involved? Minimally involved?

Do you identify yourself as (circle all that apply): a. Religious b. Spiritual c. Nonbeliever

Did you have a religious conversion experience (i.e. a marked time that called for a complete change in your life)? If so, at what age?

How strong was the religious dimension in your family?

Do you feel you have reached adulthood?
a. Yes
b. In some ways yes/In some ways no
c. No

How do you know when you've reached adulthood? Rate the criteria that are most important for defining adulthood (1-most important to 5-least important).
a. Finishing education
b. Getting married
c. Accepting responsibility for yourself
d. Becoming financially independent
e. Making independent decisions

For the following section mark one of the five choices in response to the statement.

1. This time of my life is fun and exciting.

Strongly Disagree

Somewhat Disagree

Neutral

Somewhat Agree

Strongly Agree

2. This time of my life is full of changes.

Strongly Disagree

Somewhat Disagree

Neutral

Somewhat Agree

Strongly Agree 
3. Overall, I am satisfied with my life.

Strongly Disagree

Somewhat Disagree

Neutral

Somewhat Agree

Strongly Agree

4. At this time of my life, I feel I have a great deal of freedom.

Strongly Disagree

Somewhat Disagree

Neutral

Somewhat Agree

Strongly Agree

5. This time of my life is stressful.

Strongly Disagree

Somewhat Disagree

Neutral

Somewhat Agree

Strongly Agree

6. This time of my life is full of uncertainty.

Strongly Disagree

Somewhat Disagree

Neutral

Somewhat Agree

Strongly Agree

7. I often feel anxious.

Strongly Disagree

Somewhat Disagree

Neutral

Somewhat Agree

Strongly Agree

8. I often feel depressed.

Strongly Disagree

Somewhat Disagree

Neutral

Somewhat Agree

Strongly Agree

9. I often feel that my life is not going well.

Strongly Disagree

Somewhat Disagree 
Neutral

Somewhat Agree

Strongly Agree

\section{Questions for in-person/phone/Skype interview}

\section{Focus on Religious Practices}

1. Has your prayer life changed since your FIU graduation? How has it changed? Do you have some ideas as to why it has changed?

2. Has the amount of Scripture that you read changed since your FIU graduation? Or have the ways in which you approach reading Scripture changed since your graduation? If there is change, why do you think that is?

3. How often have you attended religious services or meetings this calendar year?
a. More than once a week
b. Once a week
c. Once or twice a month
d. Less than once a month
e. Not at all

4. Has your current church attendance changed when compared to your church attendance during college? If so, what are the factors pushing that change?

5. Who/what do you look to for strength? Do you look to God for strength? If so, how often are you dependent on God for strength?

\section{Focus on Community}

1. Can you tell me something about where you're living and who you live with, if anyone? What kind of place do you live in? Parent's home, apartment, house? Who pays the bills/rent/mortgage/etc.? Do you still receive help from your parents, or are you pretty much on your own? Has your living situation changed much since your graduation from FIU, or pretty much stayed the same?

2. Describe the communities/community groups that you are part of. Since graduation, have you found Christian communities that support your religious/spiritual beliefs, offer you satisfying fellowship, and/or offer you opportunities for Christian service? If so, describe that community or communities (i.e. church, friends that share your beliefs, volunteer organizations)? How did you find them? If you have not found such replacements for your campus religious organization, why do you think you have not found an appropriate community? 
3. What kind of support from members of a Christian community would be attractive to you (i.e. support related to prayer, increasing theological understanding, social relationships, community service)?

\section{Focus on Family}

1. Have your parents been supportive during this transition out of college? How have they been involved, negatively or positively, in helping you make the transition? In what ways have they shown support (financially, spiritually, etc.)? Has their support or lack of it affected your spiritual transition from college?

2. Have you married, become engaged or seriously involved romantically since college? If so, how has that relationship affected your religious affiliations, church attendance, and spiritual life in general? If it is still in effect, how do you expect this new relationship to affect your religious and spiritual life in the next decade?

\section{Focus on Church}

1. Thinking of church services, church communities and church-related programs, is there a difference in your experience of church before and after graduation? If so, how would you describe it?

2. What are the main kinds of support you look for from a church community? If you have a congregation, explain how your congregation meets or could better meet those needs. What are some specific ways in which church leaders could better connect with your age group?

\section{Focus on Theology}

1. How has your understanding of Christian theology changed, deepened, or been challenged by your experience since graduation?

2. Are there any theological concepts to which you feel more, or less, committed since your graduation? Are there any theological concepts or interpretations of which you are more doubtful? 